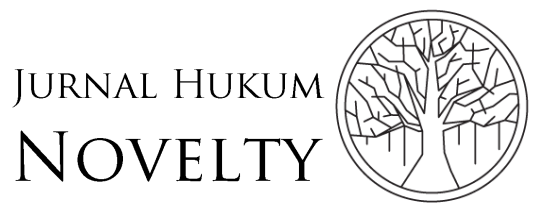

Volume 10, Issue 02, 2019, pp. 140-149

\title{
Legal Protection of Incest Victims Who Have an Abortion
}

\author{
Achmad Prasteya Putra Syailendra ${ }^{1}$ \\ 1 Postgraduate Study, Faculty of Law, Universitas Diponegoro, Indonesia \\ syailendra110@gmail.com
}

\begin{abstract}
Introduction to The Problem: Rape crime is a kind of violence against women in male sexual interests which show the position of vulnerable women. This genderbased violence is often caused by inequalities power in society or family. The annual report 2017 by the National Commission on Violence Against Women from sexual violence in private/personal sector, incest were the most reported cases as much as 1.210 cases. The incest case eventually spread to other criminal cases, for example, forced abortion by his family or the surrounding environment. The most detrimental impact of rape is pregnancy. Many rape victims can not bear the shame and disgrace; therefore, they prefer to stop their pregnancy or abortion even though abortion is illegal in Indonesia. That's why legal protection of rape victim is needed, especially when the victim has an abortion.
\end{abstract}

Purpose/Objective Study: This research aims to re-reflect the legality of abortion laws which regulated in Indonesian law. Furthermore, this research also reviewing legal protection for incest rape victims who are forced to have an abortion.

Design/Methodology/Approach: This research is using a qualitative method with a normative judicial approach. The approach is carried out by examining library materials or secondary data as a basis for review, such as regulations and literature relating to the problem. The data is parsed in a descriptive narrative structured and coherent explanation.

Findings: The rules regarding abortion in Indonesia are various, starting from those that are fully prohibited, to regulations which stated the exceptions. The rules are stated in the Criminal Code which fully prohibits abortion. While another rules legalizes the abortion for certain exceptions. Through these laws and regulations, Indonesia became a country which on the one hand absolutely prohibited abortion and on the other hand allowed abortion only for three cases, there are protecting the lives of mother, protecting fetus, and victim of rape. Abortion due to incest rape needs to be given forgiveness for the condition of the victim in charging the penalty. The psychological impact is more severe when keeping the baby because if the victim sees and raises the baby in a state of being unprepared and depressed it has bad consequences for the baby and the mother. When the victim sees the baby it will cause trauma, remembering the incident, thus will not treat the baby well and the baby's growth and development will not good either.

Paper Type: Research Article 
P-ISSN: $1412-6834$

E-ISSN: 2550-0090

Keywords: Legal Protection; Abortion; Rape; Incest Victims

\section{Introduction}

Rape crime is a kind of violence against women in male sexual interests which show the position of vulnerable women. This gender-based violence is often caused by inequalities power in society or family (Fanani, 2014). Responses to these victim interests in the judicial or social process are very important and must be considered during formulating a regulation by the executive, legislative, judicial and all relevant institutions (Wedani \& Dananjaya, 2015). According to Mansor Faqih, genderrelated violence is violence caused by gender bias. Some examples of gender violence include the rape of women, physical violence in the household (domestic violence) (Fanani, 2014).

Based on statistic data, the Indonesian Statistics Agency recorded there were 4,850 criminal cases which classified as sexual crimes such as rape in 2013. The figure ascended fluctuatively in the next four years. The sexual crime case arosed into 5,499 cases in 2,014 and decreased into 5,051 cases. The number then increased until it touched 5,513 in 2017 (Subdirektorat Statistik Politik dan Keamaan, 2018). The statistical records of sexual crimes were specifically parsed back by the National Commission on Violence Against Women. The annual report 2017 by the National Commission on Violence Against Women from sexual violence in private/personal sector, incest were the most reported cases as much as 1,071 cases. The incest case eventually spread to other criminal cases, for example, forced abortion by her family or the surrounding environment (Komisi Nasional Anti Kekerasan Terhadap Perempuan, 2019).

Concerns about incest become very troubling and dangerous for society today. Especially when incest occurs in the form of rape. The occurrence of incest often covered up, because it is shameful. Thus, this case appears and known only when it has been reported to the police. Additionally, the victims overshadowed by their fear of perpetrators, so that they would think twice to report the case. The alternative solutions of the victims are move out from their house to other relatives, or being as far as possible (Suyanto, Hidayat, Sugihartati, Ariadi, \& Wadipalapa, 2019). The gap between the occurrence of the case and the report to the police seems to be a safe period for the perpetrators in the victim's family to commit his amorous acts. The interesting part is when the closest environment tends not to know from the beginning about the incest. There are also veils of language that surrounds incest and sex in daily talks. This means at certain stages the social structure contributed to the occurrence of the incest case (Surya Nugraha, 2018).

The most detrimental impact of rape is pregnancy. Many rape victims can not bear the shame and disgrace; therefore, they prefer to stop their pregnancy or abortion even though abortion is illegal in Indonesia. That's why legal protection of rape victim is needed, especially when the victim has an abortion. Does the rape victim 


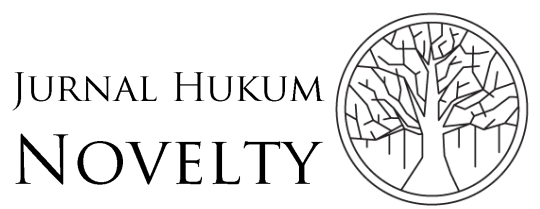

Volume 10, Issue 02, 2019, pp. 140-149

get legitimacy that alleviates the abortion? The victim's condition is noteworthy so that the decisions that already taken affect the benefit. As stated by Satjipto Rahardjo, the law is for human, not human for the law. This statement will broadly touch on things that are beneficial for human life (Savitri, 2008).

Based on those backgrounds, this research brings some questions as follows, 1) what is the formulation policy on abortion in Indonesia? and 2) how is the legal protection for victims of incest rape who have an abortion? This research aims to rereflect the legality of abortion laws which regulated in Indonesian law. Furthermore, this research also reviewing legal protection for incest rape victims who are forced to have an abortion.

\section{Methodology}

This research is using a qualitative method with a normative judicial approach. The approach is carried out by examining library materials or secondary data as a basis for review, such as regulations and literature relating to the problem. The data is parsed in a descriptive narrative structured and coherent explanation.

\section{Results and Discussion}

\section{Abortion Formulation Policy in Indonesia}

Abortion has been discussed for a long time as part of the legal issues which debated the legality. Even now, it becomes an integrative part of social life, when an unwanted pregnancy occurs. There is a lot of legal status of abortion; some allow it on request, while others are fully forbidden (Guillaume \& Rossier, 2018). Based on the legal category of abortion, Reed Boland and Laura Katzive divide this case into five legal statuses of abortion throughout the world. The first category is the country which fully prohibits abortion except to save the lives of pregnant women. The second category is the country which allows abortion to protect women's physical health of women. The third category is the country that allows abortion based on mental health. The fourth category is the country that allows abortion for socioeconomic factors. The last is the country that allows abortion without any exceptions (Boland \& Katzive, 2008; Mintarsih, 2017). Different from Reed Boland and Laura Katzive, Yilda Arzu Aba et.all. divides the categories into eight kind, namely 1) abortion is absolutely prohibited; 2) permitted abortion for the sake of saving the women's life; 3) permitted abortion for the sake of protecting the physical health of women; 4) permitted abortion for the sake of protecting the psychological health of women; 5) permitted abortion specifically to victims of rape or incest; 6) permitted abortion due to fetal abnormalities; 7) permitted abortion based on socioeconomic factors; and 8) fully permitted abortion (Aba, Aba, Özkan, \& Güzel, 2016).

Abortion seems still a 'popular' epidemic that spreads throughout the world. One of the countries that have problems related to abortion is Indonesia, where Indonesia contributes 2 million abortion cases per year (2000), which majority carried out by 
people who unlicensed and has no medical capability (Jurnalis Uddin, 2002). This number is surprising, by Sedgh $\mathrm{G}$ and Ball $\mathrm{H}$, this number is explained with $54 \%$ cases of abortion is carried out by high school graduates and $21 \%$ of high school/academy/university graduates. Even more, the abortions that happened in Indonesia are unsafe, causing an increase in the mortality rate of women/mothers (Sedgh \& Ball, 2008).

In general, abortion leads to the death of a fetus in a woman's uterus. Thus, aborted pregnancy is interpreted as the process of aborting the pregnancy intentionally or a process/mechanism to make a fetus in the womb fail to develop/live (Tanuwijaya, 2014). Abortion is part of a criminal as a side effect from rape that causes pregnancy (Perry, Murphy, Haider, \& Harwood, 2015), although it does not specifically occur in rape, because it can also occur in the pregnancy of a legal partner (husband and wife) which then aborted for one reason or another (Uddin, 2002). When rape is considered as an unethical and amoral act, thus it is called an immoral act (Aji Saputra \& Soponyono, 2018), then abortion becomes part of an immoral act which is prohibited by law.

The rules regarding abortion in Indonesia are very various, starting from those that are fully prohibited, to regulations which stated the exceptions. By law, abortion is regulated in the Indonesian Criminal Code. The regulations that regulate the legality of abortion in the Criminal Code are mentioned in Articles 346-349. Article 346 of the Criminal Code states that a woman who has an intentional abortion or asks someone else to do it thus will subject to a sentence of 4 years in prison. While Article 347 of the Criminal Code states that anyone who intentionally had an abortion without the consent of a pregnant woman, is subject to a 12-year prison sentence. This sanction will increase to 15 years in prison if an abortion in these conditions causes the death of a pregnant woman. Article 348 states that someone who helps an abortion even with the mother's consent will still be subject for 5 years and 6 months in prison. The sanction increases to 7 years if it causes the death of the mother. Lastly, Article 349 states that referring to 3 previous Articles, if an abortion is performed by a doctor, nurse, or midwife, then sanctions will be given by the conditions in the previous articles with an additional one-third sentence and revoked license of practice (Yospin, 2015).

Looking at the contents of the four Criminal Code articles on abortion, it can be concluded that abortion is an act that is fully prohibited. This applies to the mother and those who help to have an abortion, whether doctor, midwife, or nurse. The consequence of this regulation, besides penal sanctions for those who do it, it is also clearly stated that a mother is legally obliged to keep her pregnancy in any condition without exception.

However, the Criminal Code is not the only law that regulates abortion in Indonesia. In addition to the Criminal Code, other regulations are regulating the issue of 


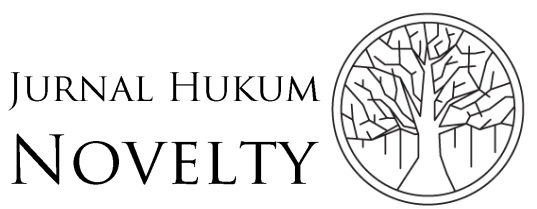

Volume 10, Issue 02, 2019, pp. 140-149
P-ISSN: $1412-6834$

E-ISSN: 2550-0090

abortion. Gradually, beside the Criminal Code, Indonesia issued Law No. 23 of 1999 concerning Health. The act of abortion is regulated in Article 15 Paragraph (1) and Paragraph (2). The article does not directly mention the word abortion, but rather with the sentence, "particular medical actions can be carried out." This particular medical action is interpreted as an abortion, referring to the previous sentence which states, "In an emergency as an effort to save the life of the pregnant mother and or her fetus." Paragraph (1) then explained in detail in Paragraph (2) that 'particular medical actions' can only be taken under certain conditions: 1) medical indications on which these actions are based; 2) consideration of the expert; 3) approval of pregnant women or husbands or families; and 4) certain health facilities. This law substantially only mentions abortion licensing to protect the safety of the mother and fetus in an emergency (Dhewy, 2017).

Law No. 23 of 1992 concerning Health was later amended by the issuance of a new law, Law No. 36 of 2009 concerning Health. Attempts to amend Law No. 23 of 1992 have a long history that is colored by various factors such as political, socio-cultural, and socioeconomic (Surjadjaja, 2008). If in the previous law the term abortion did not explicitly appear, then the term abortion began to be used in this law. Abortion regulations in this law are indicated in Articles 75-77. Article 75 paragraph (1) clearly prohibits abortion for everyone. Same as Law No. 23 of 1992, Article 75 paragraph (2) of Law No. 36 of 2009 provides exceptions, which are indications of medical emergencies and pregnancy due to rape. While technically, the prohibition is explained in Article 76, such as 1) before the age of 6 (six) weeks of pregnancy; 2) by certified medical personnel; 3 ) with the consent of the pregnant woman and/or husband's consent (except for rape victims); 4) and health service providers which are permitted by the ministry. While in Article 76, this law emphasizes the role and responsibility of the government to protect and prevent the not qualify, unsafe, irresponsible abortion which contrary to religious and legislation. The issuance of Law No. 36 of 2009 provides a new addition to the abortion exception by adding a clause on rape victims (Dhewy, 2017).

The law concerning health above is implemented through Government Regulation No. 61 of 2014 concerning Reproductive Health. Details regarding abortion are mentioned in Articles 31-39. These articles began to explain about indications of medical emergencies and indications of rape. The medical indications are seen from the pregnancy, if the pregnancy threatens the health and life of the mother or the fetus, including severe genetic diseases which are assumed to be difficult for the baby's life after birth. While related to the indication of rape, the occurrence of rape is proven by the gestational age following the rape incident based on the information from the doctor, investigator, psychologist, or other experts who can prove the existence of rape.

Based on the various laws and regulations that have been mentioned, it can be seen the stages of legality development of abortion in Indonesia. Even though the 
P-ISSN: $1412-6834$

E-ISSN: 2550-0090

Criminal Code fully prohibits abortion, this absoluteness is excluded by the issuance of the new law; Law No. 23 of 1992 concerning Health. The exception to the abortion only for one type of case; medical emergencies. Through the effort and maturation of studies of cases that occurred at that time, Law no. 23 of 1992 concerning Health was later amended by Law No. 36 of 2009 concerning Health. The change that occurred was the addition of an abortion exclusion clause in two, namely an indication of medical emergencies (both for mother and fetus) and for rape victims. Finally, the law is regulated in more detail through PP No. 61 of 2014 concerning Reproductive Health. Through these laws and regulations, Indonesia became a country which on the one hand absolutely prohibited abortion and on the other hand allowed abortion only for three cases, there are protecting the lives of mother, protecting fetus, and victim of rape (Guillaume \& Rossier, 2018; United Nations (Department of Economic and Social Affairs), 2014).

\section{Legal Protection of Incest Victims Who Have an Abortion}

Referring to the abortion regulation formulation in Indonesia, there are several types of policies that regulate it. As mentioned above, abortion laws and regulations have a different policy from one another. When we refer to the Criminal Code, abortion is prohibited for any reason. This policy is different when referring to Law No. 36 of 2009 concerning Health and Government Regulation No. 61 of 2014 concerning Reproductive Health. If the Criminal Code fully prohibits abortion, the Law concerning Health and Government Regulation on Reproductive Health states allowed with certain indications.

Regarding abortion that carried out by incest rape victim, the thing that needs to be considered as part of legal protection is that the pregnancy of the incest rape victim is unwanted. Furthermore, rape incest has a greater impact on psychological trauma due to blood relations between the perpetrator and the victim. Likewise, this incest rape case is a force of sexual intercourse which is usually accompanied by threats of violence, both physical and psychological. Victims of incest rape must receive legal protection such as restoring their mental condition due to forced pressure from other parties (psychological pressure), providing a sense of security, ensuring that they are still valuable and treating the physical injuries. Rape victims can experience very serious impacts both physically and psychologically. Physical impacts that can occur to victims as follow: (1) organ damage such as tearing of the hymen, fainting, death; (2) victims are very likely to get sexually transmitted diseases (STDs); (3) unwanted pregnancy (Ariefka, Sari, \& Yulandari, 2018). Psychologically, victims can be stricken with depression, phobias, and nightmares, victims can also be suspicious of others for a long time. Some feel restricted in dealing with others, having sex and also fears of the pregnancy as a result of rape (Sulistyaningsih \& Faturochman, 2002).

An unwanted pregnancy as a result of incest rape is the hardest impact because it damages physical and psychological simultaneously. Those reasons due to incest 


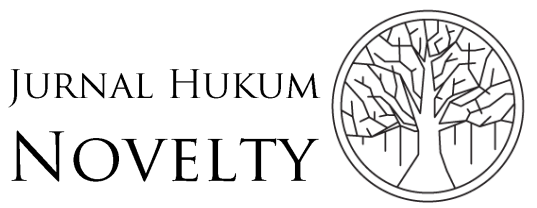

Volume 10, Issue 02, 2019, pp. 140-149
P-ISSN: $1412-6834$

E-ISSN: 2550-0090

rape should be used as a consideration to determine that abortion caused by rape is an exception, so it should be legal. Keep in mind that the law for human not human for the law is emphasized more on the benefits of justice so that the law is not rigid.

Rape itself is a criminal act which the culprit must be sentenced to a maximum imprisonment of 12 (twelve) years according to Article 285 of the Criminal Code. In particular, incest rape is categorized as sexual violence based on Article 8 of Law No. 23 of 2004 concerning the Elimination of Domestic Violence. The penalty given to the perpetrators is four to fifteen years or a fine of at least Rp. 12,000,000 (twelve million rupiah) and a maximum of Rp. 300,000,000 (three hundred million rupiah).

In addition to Article 48 of the Criminal Code concerning forced power (overmacht), Article 75 paragraph (2) letter b of Law No. 36 of 2009 also regulates the exclusion of abortion against pregnancy due to rape, recognizing the power of the force for anyone who has an abortion. The sentence that handed down by judges, must be seen from a variety of considerations and perspective, especially when making an acquittal due to forgiveness or overmacht, here the judge is faced with very mature considerations (WISUDANTO, 2013).

Article 48 of the Criminal Code which contains provisions of overmacht or forced power stated in the article: "Whoever commits an act due to the influence of forced power is not convicted." From the provisions of Article 48 of the Criminal Code, it can be concluded that what is meant by the influence of forced power is a force or pressure that cannot be avoided. The coercion is carried out by someone against another person with a threat that endangers himself and his soul. Of course, in this case, the person being threatened has a strong suspicion that the threat will be carried out if he refuses to do something that the threater wants (Susanti, 2013).

Article 48 of the Criminal Code has the meaning that if a person commits a criminal act due to an "influence of forced power" (overmacht), whether mentally or physically, the person who commits the act under the influence of forced power and this is evidently and objectively proven, according to the provisions of Article 48, the person who commits his act was "not" convicted. It is just that in a situation like this, the perspective of the overmacht must be in such a way that the person is really in a state of "impossibility", meaning that the person absolutely and objectively has no other choice but have to do those act (Makarao, 2010).

Abortion due to incest rape needs to be given forgiveness for the condition of the victim in charging the penalty. The psychological impact is more severe when keeping the baby because if the victim sees and raises the baby in a state of being unprepared and depressed it has bad consequences for the baby and the mother. When the victim sees the baby it will cause trauma, remembering the incident, thus will not treat the baby well and the baby's growth and development will not good either. There needs to be a criminal addition charge for perpetrators who do the 
rape act repeatedly. Therefore, law officers must look broadly at the possibilities. The law is focused on protecting society rather than criminal retaliation.

\section{Conclusion}

Rape is a crime against women in a kind of forced sexual intercourse. The effects of rape are not only physical but psychological. The most detrimental impact experienced by the victim is pregnancy. Pregnancy out of wedlock due to rape leaves the victim depressed and regards the child as a disgrace rather than a gift as a motivating factor for rape victims to have an abortion. Abortion in Indonesia is permitted if there are 2 reasons, such as medical indications and rape.

In Indonesia, there are several regulations regarding abortion. According to the Criminal Code, abortion is illegal for any reason. Whereas in Law No.36 of 2009 concerning Health and Government Regulation of the Republic of Indonesia No.61 of 2014 concerning Reproductive Health allow abortion based on medical indications if the fetus is endangering a pregnant parent. There are several reasons a person who commits a crime cannot be convicted as a criminal, one of them is if the perpetrator is under pressure or forced to commit the act (overmacht) this can be as a reason for forgiveness following Article 48 of the Criminal Code. An incest rape victim is under pressure and also psychological and physical suffering. This pressure encouraging the victim to have an abortion, thus they cannot be criminalized.

\section{References}

Aba, Y. A., Aba, G., Özkan, Ş., \& Güzel, Y. (2016). Abortion policies around the world and in Turkey and its reflection on women's health. International Journal of Human Sciences, 13(1), 1651-1665. https://doi.org/10.14687/ijhs.v13i1.3580

Aji Saputra, T. A., \& Soponyono, E. (2018). Criminology study on pedophilia prevention in Inonesia. Jurnal Hukum Novelty, 9(2), 117-127. https://doi.org/10.26555/novelty.v9i2.a11387

Ariefka, Y., Sari, K., \& Yulandari, N. (2018). Memaafkan pelaku perkosaan di masa konflik: Perjalanan panjang korban konflik di Aceh. Seurune: Jurnal Psikologi Unsyiah, 1(2), 58-83. Retrieved from http://jurnal.unsyiah.ac.id/seurune/article/view/11572/9115

Boland, R., \& Katzive, L. (2008). Developments in laws on induced abortion: 1998 2007. International Family Planning Perspectives, 34(3), 110-120. Retrieved from https://www.jstor.org/stable/27642866

Dhewy, A. (2017). Analisis wacana kritis terhadap pasal aborsi dalam UU Kesehatan dan PP Kesehatan Reproduksi. Jurnal Perempuan Untuk Pencerahan Dan Kesetaraan, 22(2), 147-153. Retrieved from http://www.indonesianfeministjournal.org/index.php/IFJ/article/viewFile/17 $4 / 176$

Fanani, A. Z. (2014). Berfilsafat dalam putusan hakim (teori dan praktik). Bandung: CV.Mandar Maju.

Guillaume, A., \& Rossier, C. (2018). Abortion around the world: An overview of legislation, measures, trends, and consequences. Population, 73(2), 225-322. https://doi.org/10.3917/popu.1802.0225

Komisi Nasional Anti Kekerasan Terhadap Perempuan. (2019). 
Catatan kekerasan terhadap perempuan 2018. Retrieved from https://www.komnasperempuan.go.id/file/Catatan Tahunan Kekerasan Terhadap Perempuan 2019.pdf

Makarao, M. T. (2010). Hukum acara pidana dalam teori dan praktik. Jakarta: Ghalia Indonesia.

Mintarsih, M. (2017). Abortion in Indonesia: An overview of its current legislation. International Journal of Multidisciplinary Research and Development, 4(5), 158162. Retrieved from http://www.allsubjectjournal.com/download/3068/4-519-530.pdf

Perry, R., Murphy, M., Haider, S., \& Harwood, B. (2015). “One problem became another": Disclosure of rape-related pregnancy in the abortion care setting. Women's Health Issues, 25(5), 470-475. https://doi.org/10.1016/j.whi.2015.05.004

Savitri, N. (2008). HAM perempuan. Bandung: Refika Aditama.

Sedgh, \& Ball. (2008). Abortion in Indonesia. New York.

Subdirektorat Statistik Politik dan Keamaan. (2018). Statistik kriminal 2018 (Vol. 4401002). Jakarta.

Surjadjaja, C. (2008). Policy analysis of abortion in Indonesia: The dynamic of state power, human need and women's right. IDS Bulletin, 39(3), 62-71. https://doi.org/10.1111/j.1759-5436.2008.tb00463.x

Surya Nugraha, A. T. (2018). Represi Terhadap Incest (Kajian Mengenai Kasus Incest di Kabupaten Aran Pandang). Jurnal Sosiologi Agama, 9(2), 89-104. https://doi.org/10.14421/jsa.2015.092-05

Susanti, Y. (2013). Perlindungan hukum bagi pelaku tindak pidana aborsi (abortus provocatus) korban perkosaan. Jurnal Ilmu Hukum Syiar Hukum, 15(2), 290-311. Retrieved from https://ejournal.unisba.ac.id/index.php/syiar_hukum/article/view/1470

Suyanto, B., Hidayat, M. A., Sugihartati, R., Ariadi, S., \& Wadipalapa, R. P. (2019). Incestuous abuse of Indonesian girls: An exploratory study of media coverage. Children and Youth Services Review, 96(August 2018), 364-371. https://doi.org/10.1016/j.childyouth.2018.11.034

Tanuwijaya, F. (2014). Abortion on law and moral perspective in Indonesia. Journal of Law, Policy and Globalization, 28, 21-29. Retrieved from http://iiste.org/Journals/index.php/JLPG/article/view/14975/15223

Uddin, J. (2002). Abortion from the islamic viewpoint. Jurnal Kedokteran YARSI, 10(1), 1-5. Retrieved from http://academicjournal.yarsi.ac.id/index.php/jurnal-fkyarsi/article/download/65/46

United Nations (Department of Economic and Social Affairs). (2014). Abortion policies and reproductive health around the world. New York.

Wedani, N. P. A. M., \& Dananjaya, N. S. (2015). Perlindungan korban tindak pidana perkosaan selama proses peradilan pidana. Kertha Semaya, 3(2), 1-5. Retrieved from https://ojs.unud.ac.id/index.php/kerthasemaya/article/view/11965/8270

Wisudanto, W. T. (2013). Penggunaan daya paksa sebagai alasan pemaaf oleh hakim dalam memutus perkara pidana (Studi kasus di Pengadilan Negeri Yogyakarta). Universitas Atma Jaya Yogyakarta. Unpublished Thesis.

Yospin, H. (2015). Abortion in perspective the medical and criminal law of Indonesia. Journal of Law, Policy and Globalization, 38, 22-28. Retrieved from 
P-ISSN: 1412-6834

E-ISSN: 2550-0090

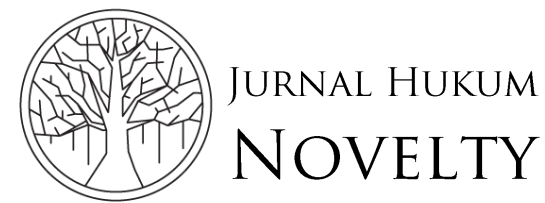

Volume 10, Issue 02, 2019, pp. 140-149

https://iiste.org/Journals/index.php/JLPG/article/view/23512 